\title{
5. The paradox of Islam and the challenges of modernity
}

\section{Kuranda Seyit}

Islam today, it would seem, has become inflexible and intolerant towards the teachings and ideologies of the West. When in fact, its history shows that it has always been accommodating to other peoples and beliefs, especially Christianity and Judaism. Most people know something of Islam. For instance, that it is one of the three monotheisms or the Abrahamic faiths and that it has much in common with Christianity and Judaism. Yet, there is so much that we do not understand about Islam and its overall world view. Islam is centred on the notion of peace, justice and community, yet when we switch on our television sets or flick through the papers there is no peace, no justice and no community; actually there is more disunity, injustice and violence in the name of God - some would argue an Islamic God.

Is there a current crisis within Islam? Are Muslims simply lost or are there complex issues at hand which are preventing intellectual development? Has the 'sacred cow of Islam' been sacrificed or is it becoming more sacred than ever, so that it is beyond criticism? And is Islam compatible with modern Western secularism, and how does Islam negotiate the sacred?

The prophet of Islam once said, 'There is no religion in Islam'. Islam is not a recent doctrine or a new set of teachings, nor is it a new ideology. 'Islam' literally means to submit to your Creator and to surrender to the divine order that exists in the universe, or to what is referred to as qadr or destiny. This, in secular terms, means to submit to the natural laws and to obey the various truths that we as humans accept as just 'being'; for instance, the law of thermodynamics, the law of gravitation, the theory of relativity, molecular and quantum physics and so on. Islam accepts all these phenomena and submits to the omnipotent power that lies behind it.

For a Muslim, the core tenet of his faith is faith itself. Hence, to be a Muslim one must submit; that is, one who has surrendered to the concept of Tawhid or unity of being and one who has accepted qadr. This is like a large mirror that is held not before you or behind you but above you, so you can see not only your own image but all that was behind you and all that is ahead. It is more about what you will do and the actions that you will take than what you are bound to. A Muslim is in a state of submission to the sacred words that defines the way a Muslim lives, as the first man Adam had done, for he too was a Muslim. 
Religion implies the belief and worship of a deity or deities and it is also a system or practice of a belief. Islam entwines all that it means to be human with the sacred; it is the conduit between our sacred heritage and the mundane existence upon Earth. Islam reminds us of our paradisaical origins, our place of creation, and our eventual home (to which we will return). Islam, therefore, is not simply a religion; it is nature and our common purpose and it is humankind's search for its innate understanding of the divine.

When Adam and Eve left their paradisaical abode and entered a new place, barren and rugged, the very first thing that they did was to build a shrine (in Mecca). The first place they arrived at became a place of sacredness - a sanctuary of peace and unity. Both Adam and Eve (Peace and blessing be upon them both) lived for a very long time, learning the secrets of existence and adapting to the hardships of life: the pains of childbirth, and the labours of working the fields, hunting for sustenance, and dealing with the mundane nature of existence. This tells us an important truth. It tells us that we, men and women, humankind, are here for a purpose, that this purpose is inherently linked to the sacred, and that the human mind must merge its rationality with sacredness and re-emerge as a whole, in unison with one's existence and environment. Therefore, natural laws, natural peace and universal being are a part of the religion of man. That is, religion and nature are inextricably linked to the divine order of existence.

From an Islamic viewpoint, it is natural for humans to be engaged in an awakening to the sacred presence in their own constitution. This presence may not be apparent to some at first, but will develop over time. It is a central component of Islamic theory that all humans are born with fitra. That is, an innate understanding of God, innocent and free from all forms of corruption. It is almost an instinctive aspiration toward transcendence. It is not until the human grows up and is indoctrinated with different ideologies and concepts that one takes a certain path or conviction of the truth as perceived by that person under the conditioning that he has been exposed to.

The prophet said, 'Every new-born child is born in a state of fitra, it is the parents (social influences) that make him Jew, Christian or Zoroastrian'. This is the idea of fitra that has aroused numerous theological commentaries, because it is so central to the Islamic concept of the sacred:

So set thy face steadfastly to the one ever-true faith turning away from all that is false, in accordance with the natural disposition (fitra) which God has instilled into man; for not to allow any change to corrupt what God has thus created - this is the purpose of the one ever-true faith; but most people know it not. ${ }^{1}$

The Islam of the seventh century, which was initiated by Muhammed Ibn Abdullah, is merely a regurgitation and a conglomeration of all the preceding 
monotheistic teachings stemming from the same God of Christ, Moses, Abraham, Joseph, Zachariah, Job, John, David, Solomon, Noah and so forth, back to Adam. The beauty of Muhammed's teachings is that it completed the long line of revelations and confirmed the message that had so long ago been imparted to Adam to reinforce humankind's knowledge of the world and its purpose. Whereas preceding revelations came to specific communities, Muhammed's message was universal and eternal. Therefore, Islam is not the 1400 year old religion that it seems to be, it is older than Christianity, older than Judaism and even older than Hinduism or Shamanism; it is the original thought and the finality of revelation.

The revelations which make up the Qur'an were delivered by the archangel Gabriel over a period of 23 years, the first when Muhammed was 40, and the last in his sixty-third year, a few months before he died. Muhammed and the Meccans already knew much of the monotheism before their time; these were mostly taught as stemming from Abraham, and so elements of this faith were still practised. Of course, the teachings of Jesus were nominally accepted as well, and the highly ordered and morally sophisticated practices of the Jews were respected amongst the pagan Arabs. In general, the pure teachings of Abraham, Moses and Jesus had been neglected and the general code of conduct in society was relatively lawless and grossly barbaric, especially towards slaves, women and children (and also animals). Therefore Islam, as taught by the Prophet Muhammed, reiterated much of what Abraham had said in that there is no deity but Allah (the God). Idolatry was condemned and polytheism denounced by the Qur'an. But certain esoteric information that had never been recorded before under a divine writ was now entailed within the pages of the Qur'an.

Islam prescribed a number of laws that governed the way a Muslim should conduct his or her life, and it revolutionised societies forever. It taught us that men and women were equal. It put an end to infanticide and cruelty to slaves. It gave women the rights of equality, to inheritance, and to the ownership of property. It gave prisoners of war rights they had never imagined and it even gave animals and trees rights. Most important of all, it showed a pathway to peaceful co-existence and tolerance toward one's fellow human beings. Islam, as it came to be known, was a comprehensive way of life, and the Shari'a became a template for all Muslim societies. So to be Muslim meant to live by a certain standard that is explicated by the Qur'an and personified by the Prophet.

Islam, in this sense, is a new identity and a new society, and therefore it will have an associated and developed culture. When one takes an oath to become Muslim, he or she is surrendering to the natural laws that exist: the laws of one omnipotent Creator. All wrong-doings of the past are wiped clean and that person is re-born and re-united with their original fitra.

Theoretically, if a person declares himself a Muslim, he is renewing his relationship with God and allowing God to dictate the terms of his existence. 
Islam is unique in that it did not create a new way of thinking or a new set of beliefs. Islam renewed humanity's relationship with the Earth and Muhammed was a reformer (guided by God) who changed the direction and state of the Arab people and affected the way people viewed the world forever.

There is no religion in Islam, as Islam and humanity are one and the same and cannot be divided into separate institutions. All human beings are in touch with the sacred, there are no barriers and no-one is excluded from access and equity.

The notion of religion as a distinctive practice is a relatively recent idea, founded in Western thought. In the sixteenth and seventeenth centuries, modern man tried to identify his relationship with God and to reinterpret faith. The new intellectuals began to think of ways of separating humans from God, and eventually from the state and from the purpose of being altogether. In Western Europe, religion was banished to the fringes as liberalism became the 'religion' of the West: secularism had begun to take root.

Paradoxically, it was under this new secularism that a new schizophrenia developed in the West. Islam was relieved of such a dichotomy and hence did not develop complex debates revolving around the place of religion in an ever-growing capitalist society. In the Islamic world, the sacred was preserved and remained a part of the public domain, albeit at the expense of political and economic progress.

This fateful dichotomy, upon which most of modernity's self-authentication hinges, owes its genesis to one of the bittersweet ironies of history. Hanna Arendt argues that its roots lie 'in the sacred nature of Roman politics' where religious and political activity could be considered almost as identical. ${ }^{2}$ Arendt points out:

For Romans the binding force of authority "more than advice and less than command" is closely connected to the religious force of auspices. Further, this conception of authority is similar to that of the Sunnah in the Islamic tradition: precedents, deeds of the ancestors and customs that grow out of them are deemed paradigmatic and binding. However, when the church succeeded in overcoming the anti-political and anti-institutional tendencies of the Christian faith and embarked upon her political career in the fifth century after Constantine the Great, she adopted the Roman distinction between power and authority. ${ }^{3}$

Waghid explains the process of secularisation more fully, and explains why it cannot occur in Islam:

Secularisation is more than a process in the mind, a loss of religious belief and an acceptance of the scientific view of the world. It is an institutional arrangement and an ideational division of labour whereby the sacred is 
separated from the realm of power. In the case of traditional Islamic societies where the sacred had no special retreats and the secular had no boundless freedom outside them, it went unnoticed. ${ }^{4}$

Manzoor further states that:

Although the Muslim state as an institution was all-pervasive and never had to contend with the challenge of the non-existent church, in terms of ideology it was a different matter all together. The state despite its absolute power never succeeded in establishing its autonomy and legitimacy and thus remained merely the coercive forearm of a political society that could have no pretence to any redemptive functions. The body politic of Islam expressed its ultimate aspirations through the sacred law, whose legitimate guardians were the ulama and not the sultan. In other words civil society was sovereign over state. And the ruler did not represent the body politic but merely embodied his personal rule or misrule. Or seen differently the state as the locus and seat of sovereignty did not exist. ${ }^{5}$

As the institutions of the Muslim community developed in the early centuries of the Islamic era, the people of knowledge or ulama emerged as a major grouping within Muslim societies. It is in this very noble body of scholars that the fate of Islam lay. In the thirteenth century, with the transition of power from the trustees of Islamic knowledge to the guardians of the state, the boundaries of the sacred also shifted, and in many ways the distinction was blurred. To this day the distinction is still in a state of confusion within the Islamic mindset.

Edward Shils writes that the intellectuals were responsible for 'the care of the sacred through the mastery, interpretation and exposition of sacred writings and the cultivation of the appropriate mental state or states were the first interests of the intellectuals'.6 The importance of the ulama within Islamic society is reflected in a quote by the prophet namely, 'the scholars are the heirs of the prophets'. The famous fourteenth-century Muslim scholar Ibn Khaldoun, explained that this meant:

People who combine practical and theoretical knowledge of the law of religious scholars, the real heirs such as the jurists among the people of the second generation, the ancient Muslims, the four founders of the schools of law as well as those who took them as models. ${ }^{7}$

The ulama were not officially part of the Caliphate; they acted as critical intellectuals often providing powerful critiques of existing conditions. 'The ulama regarded themselves as the collective voice of the conscience of society' ${ }^{8}$

Already by the thirteenth and fourteenth centuries, the lines were drawn between what might be thought of as the ulama bureaucrats and the ulama intellectuals. 
For some the conviction developed that it was better to accept the decisions of earlier thinkers rather than to engage in independent, informed interpretation, while others saw such independent analysis as the continuing responsibility of appropriately learned scholars. This was the conflict over taqlid (imitation) and ijtihad (independent judgement).

Ijtihad plays an important role in understanding the development of Islamic theory and the science of interpretation. Ijtihad may be defined as independent reasoning and judgement used in cases when an issue is not clearly defined in the Qur'an or by the Sunnah. It is not an exact science and for many scholars a controversial course of action in the first place.

In the eleventh century, Abu Hamid al-Ghazzali (1058-1111) made a permanent impact on the way Muslims perceived their faith. He reverted to the practice of ijitihad and believed that he had the right to make fresh interpretations of the verses in the Qur'an and of Ahadith, previously accepted as authentic and immutable. The accepted standard practice of the time was called taqlid or 'to copy' or follow the interpretations made by previous scholars.

The 'gates of ijtihad' had been announced closed by the ulama since the middle of the tenth century. Islamic theology and jurisprudence hitherto had relied on the authority of the traditions that had been developed in the first three hundred years of Islam. The ulama, or intellectual class, had withdrawn inwards and their influence on the hierarchy was in decline. However, Islam could not develop without some relationship with the scholars and in the mid-nineteenth century, new forms of intellectualism were developing.

But several centuries before, there were scholars who challenged the conservatism of the time. Ibn Taymiyya (1263-1328), a great Hanbali scholar, stressed the need for all Muslims to follow the obligations of their faith. No-one was free from the obligation to encourage virtue and to condemn vice. Ibn Taymiyya claimed the right of ijtihad and used his independent judgement in rearticulating the general principles provided by the Qur'an and the sunnah (tradition). In his strong criticism of both political and communal life of his time and the way he articulated that critique he helped to define the intellectual's alternative to the stable ulama establishment that was emerging by the thirteenth century.

The ulama had developed as something different - as the people of knowledge, acting as intellectuals in Muslim societies. As officials, the ulama were a significant part of the state structure and the institutions of the status quo in the sixteenth century, at the peak of power of the Ottoman Empire.

The prophet said 'the nearer a man is to government the further he is from God'. The tension between the intellectuals and the powers comes ultimately from the constitutive orientation of the intellectuals towards the sacred. Within Islamic traditions, the critical Muslim intellectual tradition takes a tajdid (renewalist) 
rather than a romantic or scientific mode. In the Muslim world, three developments have been of special importance in the emergence of the Muslim activist intellectuals during the final decades of the twentieth century.

Firstly, as a part of the interaction with the West and the consequent westernisation and modernisation of the Muslim society, a grouping of secular intellectuals occurred. Secondly, there was a significant decline in the importance of the classically defined ulama among the intellectuals of Muslim societies. Thirdly, by the end of the nineteenth century a new kind of intellectual had emerged. In this new intellectual, characteristics of both the modern intellectual and the classical ulama were visible, at first often in an uncomfortable compromise, and then in increasingly effective synthesis.

The history of intellectuals in Muslim societies provides an important foundation for activist reforming intellectuals in the twentieth century. According to Esposito,

After the first world war a new breed of intellectuals emerged, orientated in Western and secularist directions...Islam among the educated strata was absorbed into secular ideology....and the group that gained undisputed political ascendancy in both Egypt and the Fertile Crescent was the Muslim secularist. ${ }^{9}$

The best example of a secular model being successfully implemented in an Islamic society is arguably Turkey. However, by 1990 it was clear that the secular intellectuals and the political elite of which they were a part had been unable to transform their secularist and semi-secular ideologies into mass movements or to reconstruct the world view of the majorities in their societies in a more secularist way. The modernising and westernising secular intellectuals succeeded in providing the world view and visions for the political elite that had been created by the transformations of the past two centuries. Most states in the contemporary Muslim world are based on ideological foundations provided by the secular intellectuals in Muslim societies. By the 1990s, this form of secularism was being challenged by the older pure forms of secularism, even in countries like Turkey.

The failure of the old style ulama to provide any real alternative to the secular intellectuals in the ninteenth and early-twentieth centuries may be the single most important aspect of the rise of the contemporary Muslim activist intellectual. The failure of the secularist intellectuals to connect with the masses would give way to a modern, but not secular, alternative to both the conservative and secularist intellectuals. To a certain degree, the new intellectual's perspective peripheralised the old secular intellectuals and converted the traditional ulama into more activist Islamic advocates and reformers. 
What modern thinkers attempted to do was to create a Muslim approach that could be both authentically Islamic and effectively modern. Esposito points out that,

Tahtawi, a nineteenth-century Egyptian scholar who spent some time in Paris, believed it was necessary to adapt the Shari'a to new circumstances and that it was legitimate to do so...if the ulama are to interpret the shari'a in light of modern needs, they must understand what the modern world is. ${ }^{10}$

Tariq Ramadan, a contemporary writer based in Europe, talks about 'how to be at the same time fully Muslim and fully Western'. ${ }^{11}$ Ramadan recognises that many young Muslims believe they have to make a choice between assimilating to Western culture and thus losing their own culture and isolating themselves from the mainstream culture. But he claims that there is no choice that has to be made. In To Be a European Muslim, he wrote,

Whereas one might have feared a conflict of loyalties, one cannot but note that it is in fact the reverse...Loyalty to one's faith and conscience requires firm and honest loyalty to one's country: Shari'a requires honest citizenship. $^{12}$

Other Muslims believe that shari'a is incompatible with modern European societies. One writer, Professor Bassam Tibi, believes that to acknowledge a meaningfully reformed Islam one must embrace the pluralistic spirit of the Western Enlightenment. He says,

In the context of religious tolerance - and I write this as a Muslim - there can be no place in Europe for Shari'a...Shari'a is at odds with the secular identity of Europe and is diametrically opposed to secular European constitutions formulated by the people...secular democracy based on the separation of religion from politics; a universally accepted pluralism; and a mutually accepted secular tolerance. The acceptance of these values is the foundation of a civil society. ${ }^{13}$

But many more call for a progressive Islam that can blend in with Western secularism, and, since September 11, believe that it is crucial that Muslims assert their willingness to join the great Western tide of civil society and just liberalism.

D. Caldwell, religion producer for Beliefnet.com, has interviewed several Muslims who hold this view. One, Omid Safi, a Qur'anic scholar at Colgate University, sees Islam as a religion which holds the key to the future of humankind and through its universal brotherhood has the potential to unite the fundamental sacralisation of modern humanism and thought. Caldwell quotes Safi as saying, 'The sad fact of the matter is there are genuine voices of fanaticism in the Muslim community. How do these hateful voices function in our community? Why are 
we silent when they talk right next to us ${ }^{\prime 14}$ According to Caldwell, Safi is frustrated by 'Muslims' lack of "active wrestling" with the faith':

"On one hand, you have reformers who want to throw out the entire thing, and on the other hand, you have people who feel completely bound by it because one jurist said one particular thing in the 14th century", Safi said.

Mostly, average Muslims are exposed to what Safi calls 'testosterone Islam', run by men, many of them engineers and physicians, who are drawn to spare Wahhabi theology. Safi says their line of thinking goes like this: 'Islam is sick. We need to heal it. We need to do this and this and this.' Or: 'The circuit of Islam is broken. If we attach this and fix this, it will work. ${ }^{15}$

A contemporary of Safi is South African progressive scholar Farid Esack. Caldwell's interview summarises Esack's views this way:

"Muslims in general cannot live with people of another religion in a state of what I call 'coolness'".

That is because, he says, "right now they have only two models for understanding their place in the world. The first is that of the oppressed as Muslims were in their early days in Mecca. The second is that of rulers, the way Muslims eventually lived in Medina."

Esack says, however, "that embedded in the Qur'an is a story about a group of Muslims who lived in Abyssinia, a Christian kingdom. There they lived peacefully neither trying to convert Christians, nor being proselytized by Christians". "That's the way for Muslims to go", says Esack. 16

These ideas are from a new breed of emerging modern intellectuals that believe that Islam can live hand-in-hand with the West. However, it appears that there are certain conditions for the merging of the ideas that will eventually happen over time. Some see it as a balance of social cohesion, and others see a transformation of Islamic thought which recognises the need for interpretation with caution and a reassessment of the relationship of Islam and the West, as had occurred in the middle centuries.

However, many of these scholars do not want to be seen as innovators (creating Bidah), by trying to change the inviolable and pure teachings of Islam that they believe were assembled 14 centuries ago. This is the position held by the swelling movement known as Salafi, which may be found in Indonesia, Afghanistan, Pakistan and Saudi Arabia, where it originated. Their strict observance of the traditions, and their reference point, beginning in the seventh century, are two major stumbling blocks to a friendship with the West. 
They can do little to stop the natural inclination of Islam as a dynamic and changing phenomenon, however Islam changes almost at a constant rate and in every century. Islam has always had a strong tradition of critical thought. It has always been able to respond to the demands of a changing world, and it has, of course, been in the forefront of scientific research and discovery. After the devastating invasion of the Mongol hordes in the twelfth century, Muslims withdrew inwardly; the Golden Age was over, there was little scope for debate and discussion, and, hence, Islam began its slow decline.

It is incongruous from an Islamic historian's perspective, but Islam today appears to be stuck in a quagmire of ignorance, superstition and conflict. Islamic thought and philosophy seem out of place in a fast and furious twenty-first century. It would appear to be inflicted with a serious malaise. But is there something more complex behind the deceleration of what was once a flourishing empire of ideas? The neo-conservatives of America would hope that the emergence of twentieth-century Western democracy and secularism as a dominant force in the world has overshadowed Islam's revival and foreshadowed its painful demise towards a cataclysmic end. The fight to 'put the sick man of Europe out of its misery' once and for all by an injection of modern secularism, and to discard Islam on the trash heap of previous victims of 'isms' (Feudalism, Monarchism, Nazism, Fascism, Communism, Socialism and others) and failed ideologies appears to be gaining momentum.

Muhammed was, in his century, a great prophet, a statesman and above all a reformer. He, like Zoroaster, Buddha, Krishna and even (more recently) Gandhi and King, revolutionised the way people think. He defied the common law, upset the status quo and built a new society based on God's law: this society respected order, compassion, rationality and justice. So he found a common ground between universal Islam and humanity. We refer to it as Islam but we could easily call it the Arabian Revolution, and frame its evolution in the same context as the French revolution. The laws of Muhammed as embodied in the words of God through the Qur'an preceded the Magna Carta, the French Declaration on the Rights of Man and the United Nations Universal Declaration on Human Rights in 1948. So as a natural development of societal laws and conduct, we can see a definite pattern of reform and change. The Arab world was transformed into something it had never seen before and could not imagine; not only in material wealth, but in spiritual, scientific, technological, artistic, literary and cultural wealth. The renewal of Islam, or submission, was to reintroduce the notion of justice and freedom, equality, brotherhood and tolerance, and, most significantly, virtue and chivalry into a world that was generally recognised as seeped in ignorance and barbarism.

What we as modern universal thinkers must recognise is that Islam is a part of our traditions and played a significant role in the development of Western human 
thought. Therefore, there is no need to reform Islam per se, but there is a need to re-shape our approaches, and our relationships, and to treat each other with acceptance and dignity. Let me stress that re-interpreting the texts is not reforming them. The prophet said that we would need to do exactly that for every age, and to apply critical thinking with balance and reason.

Islam is intrinsically a part of the natural law and the cosmological nature of life. Muslims, although they admit to practising certain customs and traditions that were initiated by Adam and Abraham, and reiterated by Muhammed, do so out of their natural instinct or fitra, and follow a path that will lead them to the sacred and to eternal happiness. This is perceived as religion.

However, whatever we refer to it as, the Arabian Revolution or Islam, the ideology borne out of it, as an entity it depends on the interpretation of the sacred texts and traditions by expert scholars, and the direction of its future depends on the potential for independent interpretation or ijtihad.

For Islam science is sacred. Man is both a spiritual and physical entity. The path to God is through our investigation of the physicality and transcendence of the same reality. For Muslims, every act is sacred, and every passing of time is impossible without the permission of God. Yet, the challenge for Muslims is the application of their sacred foundations to the mundane physicality of this realm: the realm of existence. We are in a constant state of flux and people must continually adapt and reshape their understanding of this nature, and to look for the signs that remind us of our original nature. The merging of the two, without compromising either one, is the penultimate challenge to succeed, not only as one in a state of submission, but also as one might in a state of vice-regency. This is the responsibility that humankind has accepted.

There is no doubt that there are fundamental clashes with secularism, and to some degree with Western liberalism, although the commonalties are far more abundant. Islam, particularly in the West, can co-exist with liberal democracy, and in fact, enhance it and further enrich its very fabric. Islam as we know it must open the doors of ijtihad to be able to cope with modernity.

Let me leave you with a quote from the father of modern rational Islam, al-Ghazali,

Yet some of the ulama (scholars) deny the possibility of love for God and say that it means nothing more than persevering in obedience, while true love of God is impossible, except metaphorically. They also deny any intimacy with Him, or passionate longing for Him, or the delight of confiding in Him, and other consequences of his love. Thus we must of necessity deal with the matter here. 
Whoever loves God for other than God's sake does so from ignorance, for among those of insight there is no true beloved save God Most High, and none deserving of love save Him. ${ }^{17}$

\section{ENDNOTES}

1 The Holy Qur'an 30:30.

2 Arendt, Hanna 1991, Modernity and the Holocaust, cited in S. P. Manzoor, 1995, ‘Desacralisng Secularism', The American Journal of Islamic Social Sciences, vol. 12, no. 4, pp. 545-59.

3 Arendt, 1991, cited in Manzoor, 1995.

4 Waghid, Y. 1996, 'In Search of a Boundless Ocean of New Skies: Human Creativity is a Matter of Amal, Jihad and Ijtihad', The American Journal of Islamic Social Sciences, vol. 13, no. 3, pp. 353-62.

5 Manzoor, 1995.

6 Shils, Edward 1932, Intellectuals Encyclopaedia, cited in J. L. Esposito and John O. Voll 2001, Makers of Contemporary Islam, New York, Oxford University Press.

7 Mottahedeh, R. 1980, Loyalty and leadership in an early Islamic society, Princeton, Princeton University Press.

8 Mottahedeh, 1980.

9 Esposito and Voll, 2001.

10 Esposito and Voll, 2001.

11 Ramadan, T. 1999, To be a European Muslim, Leicester, The Islamic Foundation.

12 Ramadan, 1999.

13 Tibi, Bassam 2002, 'A Plea for a Reform Islam', in Susan Stern and Elisabeth Seligmann (eds), The End of Tolerance? London, Nicholas Brearly.

14 Safi, cited in Caldwell, D. 2002, 'Something major is happening. Are we witnessing the beginnings of an Islamic Reformation?', <Beliefnet.com, http://www.beliefnet.com/story/92/story_9273_1.html?rnd=94>

15 Safi, cited in Caldwell, 2002.

16 Esack, cited Caldwell, 2002.

17 Ghazali, Ihya 'Ulum al-Din (Revivification of the Sciences of Religion). 